\title{
Economic Impacts of Agricultural, Food, and Natural Resource Industries in Florida in $2004^{1}$
}

\author{
Alan W. Hodges, Mohammad Rahmani, and W. David Mulkey²
}

The agricultural, food and natural resource industries are a significant component of the Florida economy. The purpose of this report is to quantify the magnitude of these industries' contributions to the economy of Florida in 2004, updating a previous study for 2003 (Hodges and Mulkey, 2006).

\section{Methods}

Data for this analysis were obtained from the IMPLAN Professional database (Minnesota IMPLAN Group), which in turn were derived from the National Income and Product Accounts and employment data for the United States (U.S. Department of Commerce). More than 100 individual industry sectors in Florida were identified as related to agriculture, food, and natural resources, including sectors for commodity production, processing and manufacturing, and associated input suppliers and supporting services. However, wholesale and retail distribution of food and kindred products, restaurants, and other food service establishments were excluded from the analysis since these activities are not strictly related to agriculture or natural resources. The total regional economic impacts for each sector were estimated using IMPLAN input-output multipliers, which capture the indirect and induced effects of sales outside Florida, that bring new money into the region and generate further economic activity as these dollars circulate through the economy. Indirect effects represent the economic activity generated by businesses that furnish inputs to the agricultural and natural resource industries, while induced effects represent the impacts of industry employee household spending. A brief glossary of economic impact analysis terminology is provided in the Appendix. Impact estimates in this update are expressed in 2006 dollars using the Gross Domestic Product Implicit Price Deflator indices for mid-year 2001 through 2006 (U.S. Department of Commerce), which restated values for 2004 approximately 6.1 percent higher.

\section{Results}

As shown in Table 1, total industry output or sales of the agricultural, food, and natural resource industries in Florida was \$56.93 billion (Bn) in 2004. Total exports outside the state of Florida amounted to $\$ 31.82 \mathrm{Bn}$. As a result of the indirect and induced

1. This is EDIS document FE680, a publication of the Food and Resource Economics Department, Florida Cooperative Extension Service, Institute of Food and Agricultural Sciences, University of Florida, Gainesville, FL. Published December 2006. Please visit the EDIS website at http://edis.ifas.ufl.edu.

2. Alan W. Hodges, Associate In; Mohammad Rahmani, Coordinator of Economic Analysis; and W. David Mulkey, Professor, Food and Resource

Economics Department, Florida Cooperative Extension Service, Institute of Food and Agricultural Sciences, University of Florida, Gainesville, FL.

The use of trade names in this publication is solely for the purpose of providing specific information. UF/IFAS does not guarantee or warranty the products named, and references to them in this publication does not signify our approval to the exclusion of other products of suitable composition.

The Institute of Food and Agricultural Sciences (IFAS) is an Equal Opportunity Institution authorized to provide research, educational information and other services only to individuals and institutions that function with non-discrimination with respect to race, creed, color, religion, age, disability, sex, sexual orientation, marital status, national origin, political opinions or affiliations. U.S. Department of Agriculture, Cooperative Extension Service, University of Florida, IFAS, Florida A. \& M. University Cooperative Extension Program, and Boards of County Commissioners Cooperating. Larry Arrington, Dean 
multipler effects from these exports, the total output impacts were estimated at $\$ 97.84 \mathrm{Bn}$. Direct employment in the industry was 390,184 full-time and part-time jobs, and total employment impacts were estimated at 769,224 jobs (full-time and part-time). The direct value added contribution of agricultural, food, and natural resource industries in 2004 was estimated at $\$ 19.79 \mathrm{Bn}$, and total value added impacts were $\$ 43.62 \mathrm{Bn}$. Value added represents the net value created by the industry, measured as the difference between industry revenues and input purchases from other sectors, and it includes personal and business net income, and capital consumption. The labor (earned) income impact was estimated to be $\$ 26.90 \mathrm{Bn}$. Indirect business taxes paid to local, state and federal governments were $\$ 2.85 \mathrm{Bn}$.

\section{Impacts by Industry Groups and Sectors}

The five industry groups with the largest economic impacts in Florida in terms of value added were fruit and vegetable farming and processing $(\$ 7.95 \mathrm{Bn})$, forestry and forest products $(\$ 7.35 \mathrm{Bn})$, agricultural inputs and support services $(\$ 6.93 \mathrm{Bn})$, environmental horticulture $(\$ 6.76 \mathrm{Bn})$, and other food product manufacturing $(\$ 5.58 \mathrm{Bn})$. Value added impacts for the next five largest industry groups were tobacco farming and manufacturing $(\$ 3.07 \mathrm{Bn})$, sugarcane farming and refined sugar manufacturing (\$1.80 Bn), mining ( $\$ 1.91 \mathrm{Bn})$, and livestock and dairy farming and animal products manufacturing (\$1.34 Bn). Relatively smaller industry groups with value added impacts of less than $\$ 1$ billion included fishing and seafood products at \$391 million (Mn); grain and oilseed farming and processing $(\$ 114 \mathrm{Mn})$; other crop farming, including cotton, nuts, and miscellaneous crops ( $\$ 258 \mathrm{Mn})$; and wildlife hunting and trapping ( $\$ 157 \mathrm{Mn}$ ). In terms of employment impacts, the largest industry groups were agricultural inputs and services (166,835 jobs); environmental horticulture $(160,785)$; forestry, wood, and paper products $(110,823)$; and fruit and vegetable farming and processing $(107,478)$.

As shown in Table 2, some of the largest individual industry sectors, all with over one billion dollars in value added impacts, were landscape services ( $\$ 4.40 \mathrm{Bn})$, soft drink and ice manufacturing
(\$2.76 Bn), other tobacco product manufacturing (\$2.79 Bn), phosphatic fertilizer manufacturing $(\$ 2.82 \mathrm{Bn})$, agriculture and forestry support activities $(\$ 2.52 \mathrm{Bn})$, fruit farming ( $\$ 2.35 \mathrm{Bn})$, vegetable and melon farming $(\$ 2.37 \mathrm{Bn})$, greenhouse and nursery production $(\$ 2.36 \mathrm{Bn})$, fruit and vegetable canning and drying ( $\$ 2.09 \mathrm{Bn})$, paper and paperboard mills (\$1.51 Bn), sugar manufacturing ( $\$ 1.15 \mathrm{Bn})$, forest nurseries and timber tracts $(\$ 1.21 \mathrm{Bn})$, frozen food manufacturing ( $\$ 1.14 \mathrm{Bn})$, and engineered wood and truss manufacturing (\$1.03 Bn).

\section{Impacts in Florida Regions}

Regional value added impacts of agricultural, food and natural resource industries are shown in Table 3 for the nine economic regions of Florida, which were defined based on employee commuting patterns (Johnson and Kort, 2004). A map of the counties included in these regions is shown in Figure 1. Total value added impacts for the nine regions, ranked in descending order, were Miami-Ft. Lauderdale (\$11.84 Bn), Orlando (\$10.61 Bn), Tampa-St. Petersburg-Clearwater (\$6.87 Bn), Jacksonville (\$6.14 Bn), Sarasota-Bradenton (\$4.27 $\mathrm{Bn})$, Gainesville (\$1.49 Bn), Tallahassee (\$1.08 Bn), Pensacola (\$856 Mn), and Panama City (\$492 Mn).

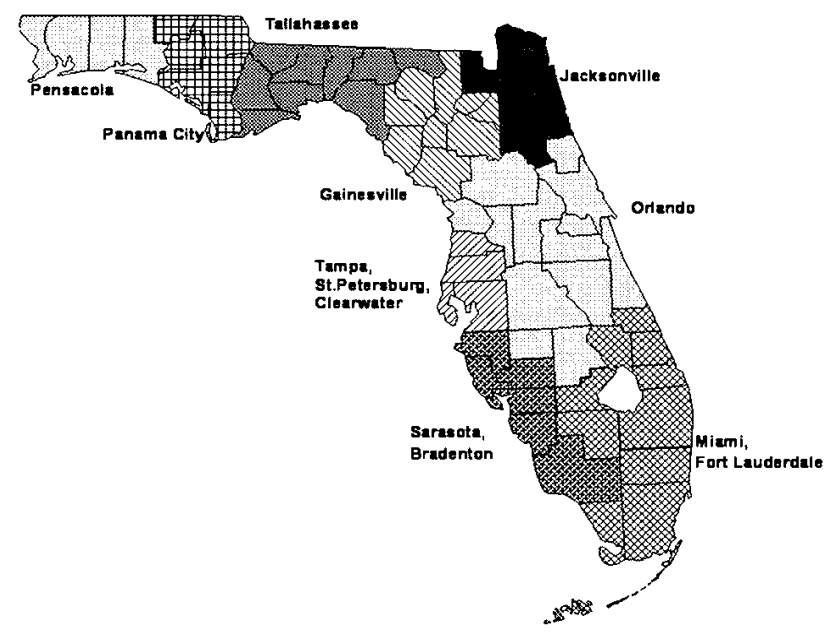

Figure 1. Economic regions of Florida.

\section{Impact Trends during 2001-2004}

Trends in economic impacts of the agricultural, food, and natural resource industries in Florida between 2001 and 2004 are shown in Table 4 and Figure 2. Total value added impacts grew from $\$ 34.94$ 
$\mathrm{Bn}$ in 2001 to $\$ 43.61 \mathrm{Bn}$ in 2004 (adjusted for inflation to express in 2006 dollars), representing an overall growth of 25 percent, or an average of 8.3 percent per annum. Total output impacts grew by an average of 13.7 percent annually, and total employment impacts increased by 0.7 percent annually. During the most recent period (2003 to 2004), there was somewhat more rapid growth in employment (1.6\%) but slower growth for output $(8.1 \%)$ and value added $(0.7 \%)$. Note that these trends in value added impacts may reflect changes in the structure of the Florida economy as well as changes in industry activity and commodity prices.
$\$ 100$ million between 2001 and 2004. Other tobacco product manufacturing increased by $\$ 1.75 \mathrm{Bn}$, or average annual growth of 49 percent; vegetable and melon farming increased by $\$ 1.19 \mathrm{Bn}(34 \%)$; landscape services increased by $\$ 1.10 \mathrm{Bn}(11 \%)$; and phosphatic fertilizer manufacturing increased by $\$ 1.03 \mathrm{Bn}(19 \%)$. Very rapid growth during this period was also seen for forest nurseries and timber tracts ( $\$ 641 \mathrm{Mn}, 37 \%$ ), engineered wood member and truss manufacturing ( $\$ 482 \mathrm{Mn}, 29 \%)$, paper and paperboard mills (\$397 Mn, 12\%), sanitary paper product manufacturing (\$396 Mn, 34\%), fruit farming ( $\$ 339 \mathrm{Mn}, 6 \%$ ), wood window and door



Figure 2. Trend in output, value added, and employment impacts of agricultural, food, and natural resource industries in Florida, 2001-2004.

Strong average annual growth in value added impacts between 2001 and 2004 was seen for the industry groups of tobacco products $(51.2 \%)$, wildlife hunting (31.7\%), other crop farming (14.7\%), and forest products $(14.7 \%)$. Moderate average growth occurred in environmental horticulture $(4.5 \%)$, fruits and vegetables (7.4\%), agricultural inputs and supporting services (6.8\%), mining (9.3\%), and other food product manufacturing $(4.5 \%)$. Negative growth occurred for grains and oilseeds (-16.7\%); fishing and seafood $(-1.4 \%)$; and livestock, dairy, and animal products $(-0.5 \%)$.

The fastest-growing individual industry sectors in terms of value added impacts are shown in Table 5 for those sectors that increased in value by at least manufacturing (\$228 Mn, 98\%), breweries (\$223 $\mathrm{Mn}, 10 \%)$, and poultry and egg production (\$214 Mn, $41 \%)$. Some other sectors that increased very dramatically in percentage terms, although not necessarily in absolute value, were cigarette manufacturing (563\%), cheese manufacturing (150\%), rice milling (59\%), fats and oils refining and blending (57\%), miscellaneous wood product manufacturing (43\%), and wineries (38\%).

\section{Implications}

The relative importance of the agricultural, food, and natural resource industries in Florida can be gauged by its share of overall economic activity in the state. The Gross State Product (GSP), which is 
the sum of value added for all industries in the state, was $\$ 625.87 \mathrm{Bn}$ in 2004 (expressed in 2006 dollars), and the total employment in the state was 9,710,846 jobs (Table 6). The direct value added contributed by agricultural, food, and natural resource industries in Florida for 2004 represented about 3.2 percent of GSP, and direct employment represented 4.0 percent of total state employment. However, when the indirect and induced multiplier effects from export sales are included, the total value added impacts of agricultural, food, and natural resource industries represented 7.4 percent of GSP, and the total employment impacts accounted for 7.9 percent of all jobs in the State. Among all industry groups in Florida, the agricultural, food and natural resource industries ranked fourteenth in their contribution to GSP.

\section{References}

Hodges, Alan W., and W. David Mulkey. 2006. Economic Impacts of Agriculture and Natural Resource Industries in Florida 2003. Electronic Data Information Source (EDIS) FE627. Food and Resource Economics Department, University of Florida, Gainesville (February). http://edis.ifas.ufl.edu/FE627.

Johnson, K., and J. Kort. 2004. Redefinition of the BEA Economic Areas. Survey of Current Business, pp. 68-75. Bureau of Economic Analysis, U.S. Department of Commerce, Washington, D.C. (November).

Minnesota IMPLAN Group, Inc. 2006. IMPLAN System (data and software), 1725 Tower Drive West, Suite 140, Stillwater, MN 55082.

http://www.implan.com.

United States Department of Commerce. Gross domestic product implicit price deflator, 1970-2006, quarterly. Bureau of Economic Analysis, U.S. Department of Commerce, Washington, D.C. http://research.stlouisfed.org/fred/data/gdp/gdpdef.

\section{Appendix: Glossary of Economic Impact Terms}

Terms are presented in groups within a logical rather than alphabetical order.
Region defines the geographic area for which impacts are estimated. Regions are generally an aggregation of one or more counties. Economic regions identified in this paper were defined based on worker commuting patterns.

Sector is a grouping of industries that produce similar products or services. Most economic reporting and models in the United States are based on the Standard Industrial Classification system (SIC code) or the North American Industrial Classification System (NAICS).

Impact analysis estimates the impact of a change in output or employment resulting from a change in final demand to households, governments, or exports.

Input-output (I-O) model. An input-output model is a representation of the flows of economic activity between industry sectors within a region. The model captures what each business or sector must purchase from every other sector to produce its output of goods or services. Using such a model, flows of economic activity associated with any change in spending may be traced backwards (e.g., purchases of plants that lead growers to purchase additional inputs such as fertilizers and containers). Multipliers for a region may be derived from an input-output model of the region's economy.

IMPLAN is a micro-computer-based input output modeling system and Social Accounting Matrix (SAM). With IMPLAN, one can estimate I-O models of up to 528 sectors for any region consisting of one or more counties. IMPLAN includes procedures for generating multipliers and estimating impacts by applying final demand changes to the model. The current version of the software is IMPLAN Pro 2.0.

Final Demand is the term for sales to final consumers such as households or government, or to exports outside of the region. Sales between industries are termed intermediate sales. Economic impact analysis generally estimates the regional economic impacts of final demand changes.

Direct effects are the changes in economic activity during the first round of spending. 
Secondary effects are the changes in economic activity from subsequent rounds of re-spending. There are two types of secondary effects: Indirect effects are the changes in sales, income or employment within the region in backward-linked industries supplying goods and services to businesses. For example, the increased sales in input supply firms resulting from more nursery industry sales is an indirect effect. Induced effects are the increased sales within the region from household spending of the income earned in the direct and supporting industries. Employees in the direct and supporting industries spend the income they earn on housing, utilities, groceries, and other consumer goods and services. This generates sales, income and employment throughout the region's economy. Total effects are the sum of direct, indirect and induced effects.

Multipliers capture the total effects, both direct and secondary, in a given region, generally as a ratio of the total change in economic activity in the region relative to the direct change. Multipliers may be expressed as ratios of sales, income, or employment, or as ratios of total income or employment changes relative to direct sales. Multipliers express the degree of interdependency between sectors in a region's economy and therefore vary considerably across regions and sectors. Type I multipliers include only direct and indirect effects. Type II multipliers also include induced effects. Type SAM multipliers used by IMPLAN additionally account for capital investments and transfer payments such as welfare and retirement income. A sector-specific multiplier gives the total changes to the economy associated with a unit change in output or employment in a given sector.

Purchaser prices are the prices paid by the final consumer of a good or service. Producer prices are the prices of goods at the factory or production point. For manufactured goods, the purchaser price equals the producer price plus a retail margin, a wholesale margin, and a transportation margin. For services, the producer and purchaser prices are equivalent.

Margins. The retail, wholesale and transportation margins are the portions of the purchaser price accruing to the retailer, wholesaler, and grower, respectively. Only the retail margins of many goods purchased by consumers accrue to the local region, as the wholesaler, shipper, and manufacturer often lie outside the local area.

\section{Measures of economic activity. Sales or output} is the dollar volume of a good or service produced or sold. Final Demand is sales to final consumers, including households, governments, and exports. Intermediate sales are sales to other industrial sectors. Income is the money earned within the region from production and sales. Total income includes personal income (wage and salary income, including income of sole proprietors profits and rents). Jobs or employment is a measure of the number of jobs required to produce a given volume of sales/production, usually expressed as full time equivalents, or as the total number including part time and seasonal positions. Value Added is the sum of total income and indirect business taxes. Value added is the most commonly used measure of the contribution of a region to the national economy, as it avoids double counting of intermediate sales and captures only the "value added" by the region to final products. 


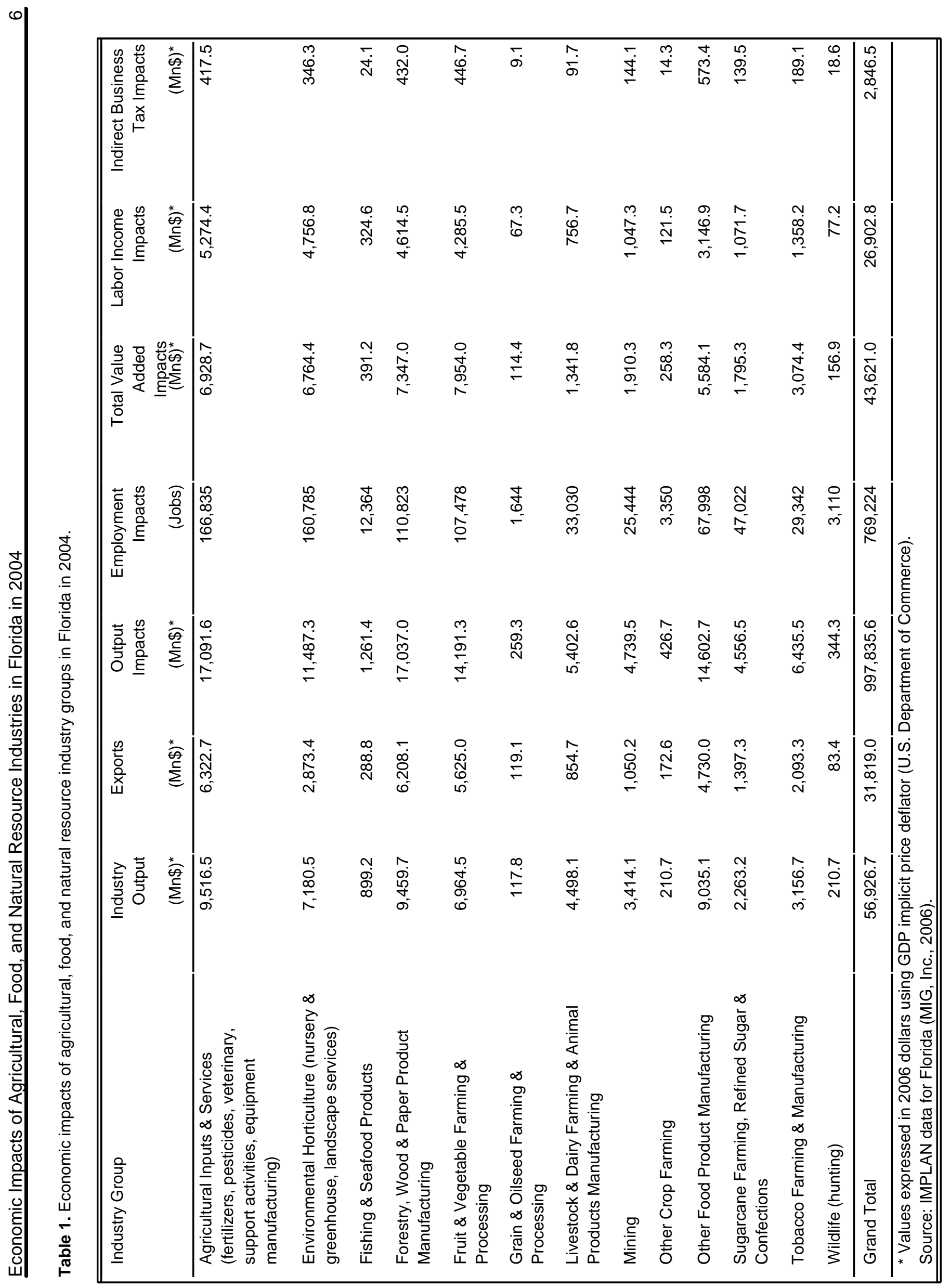




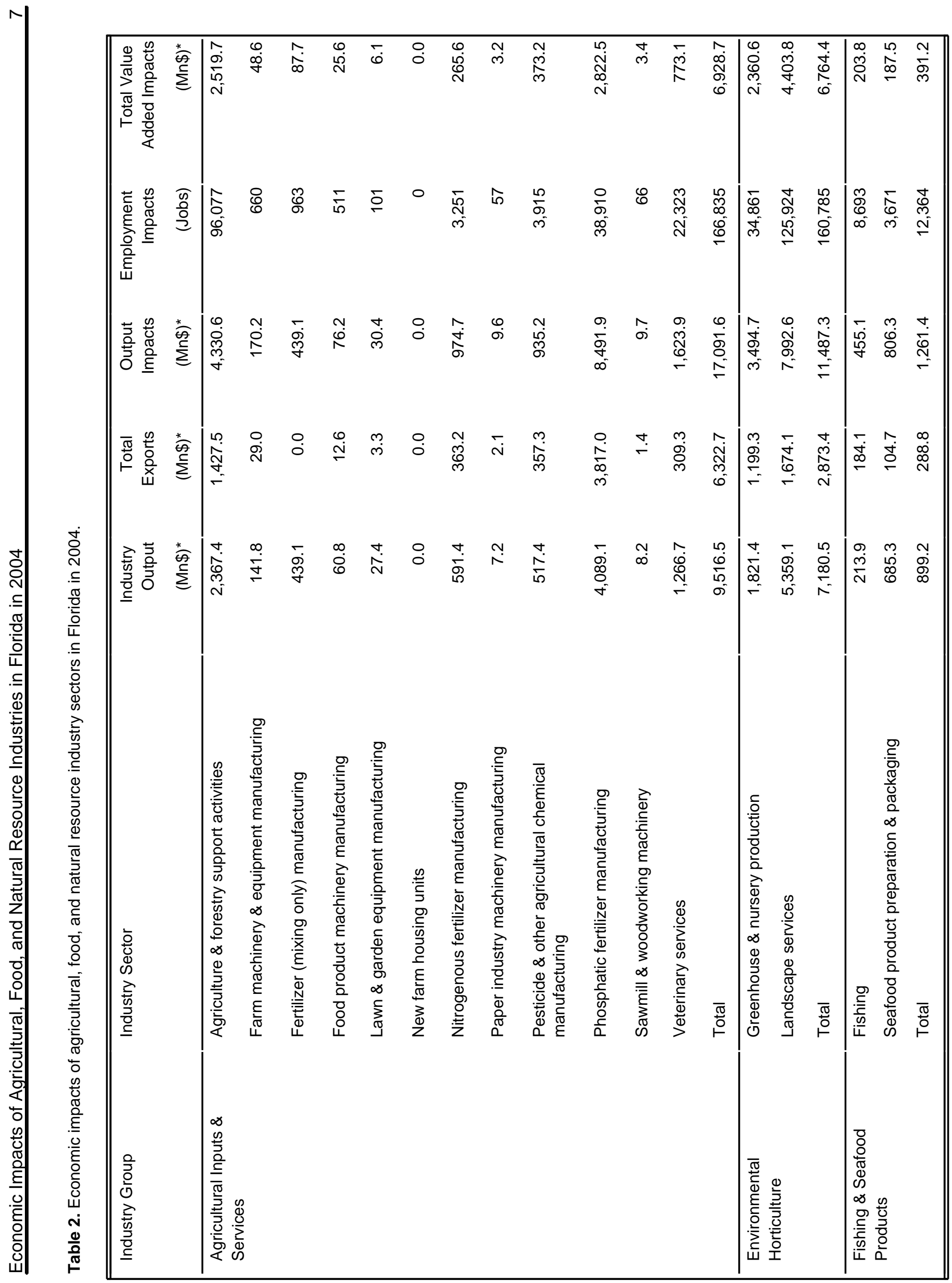




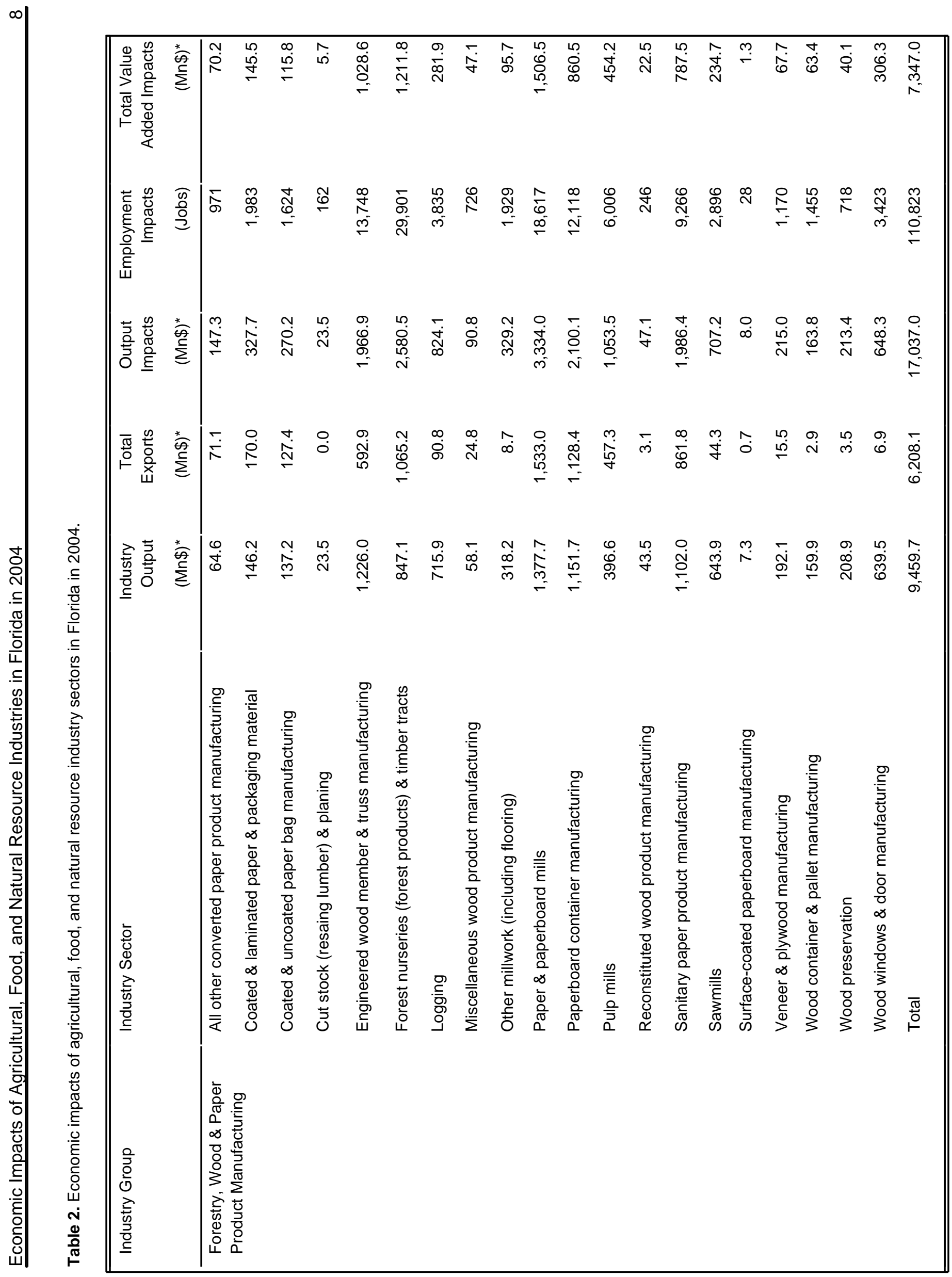




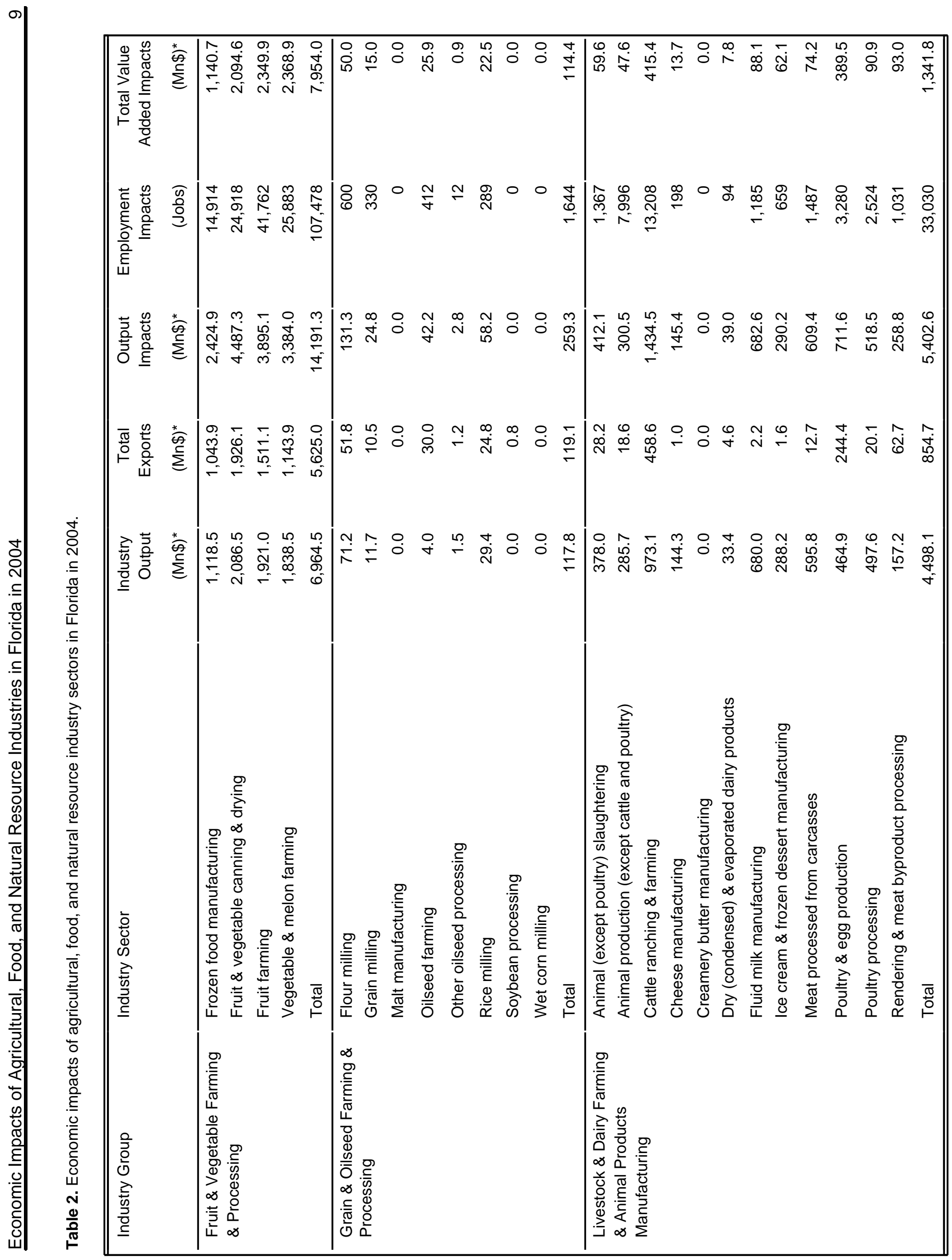




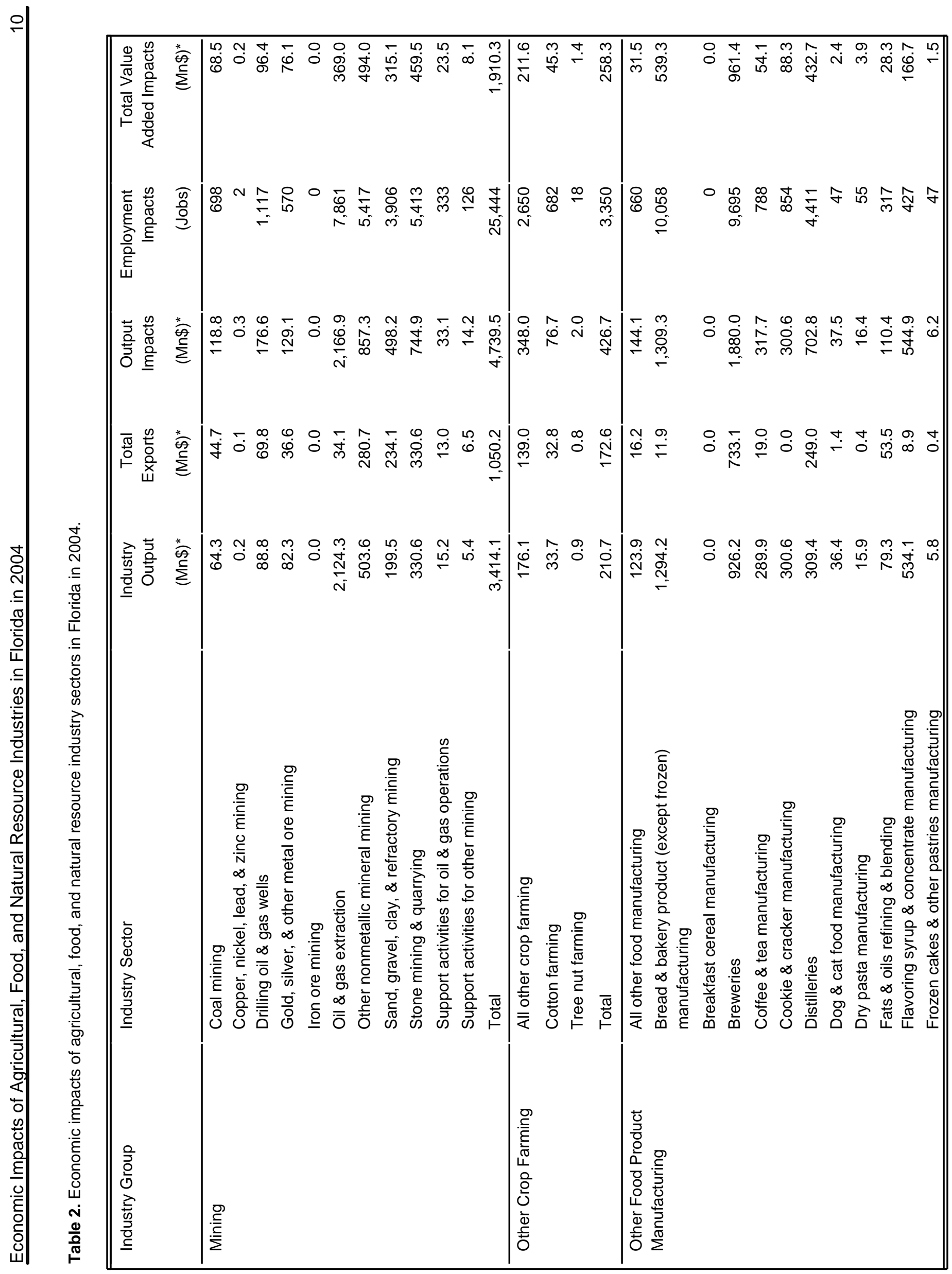









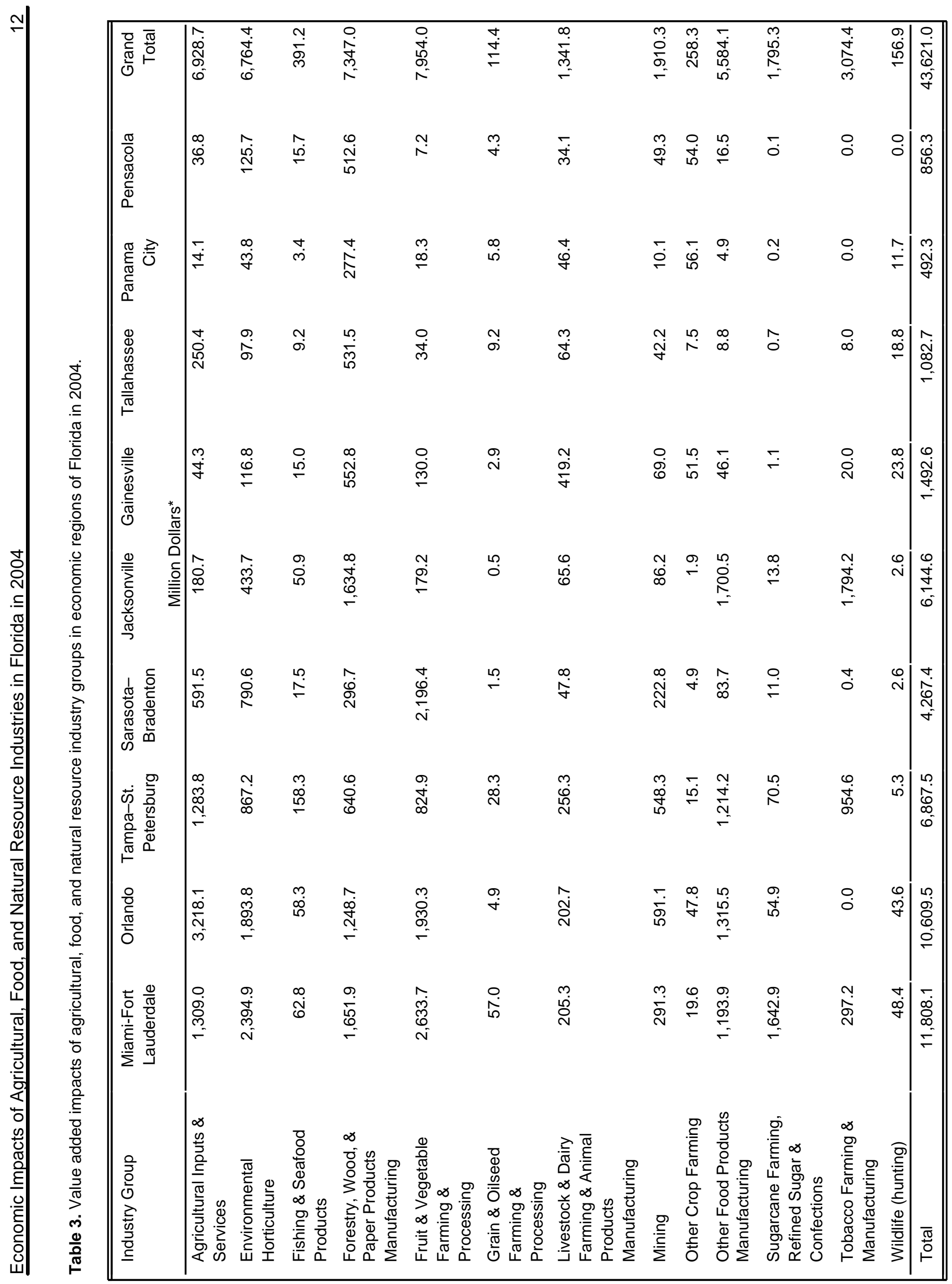




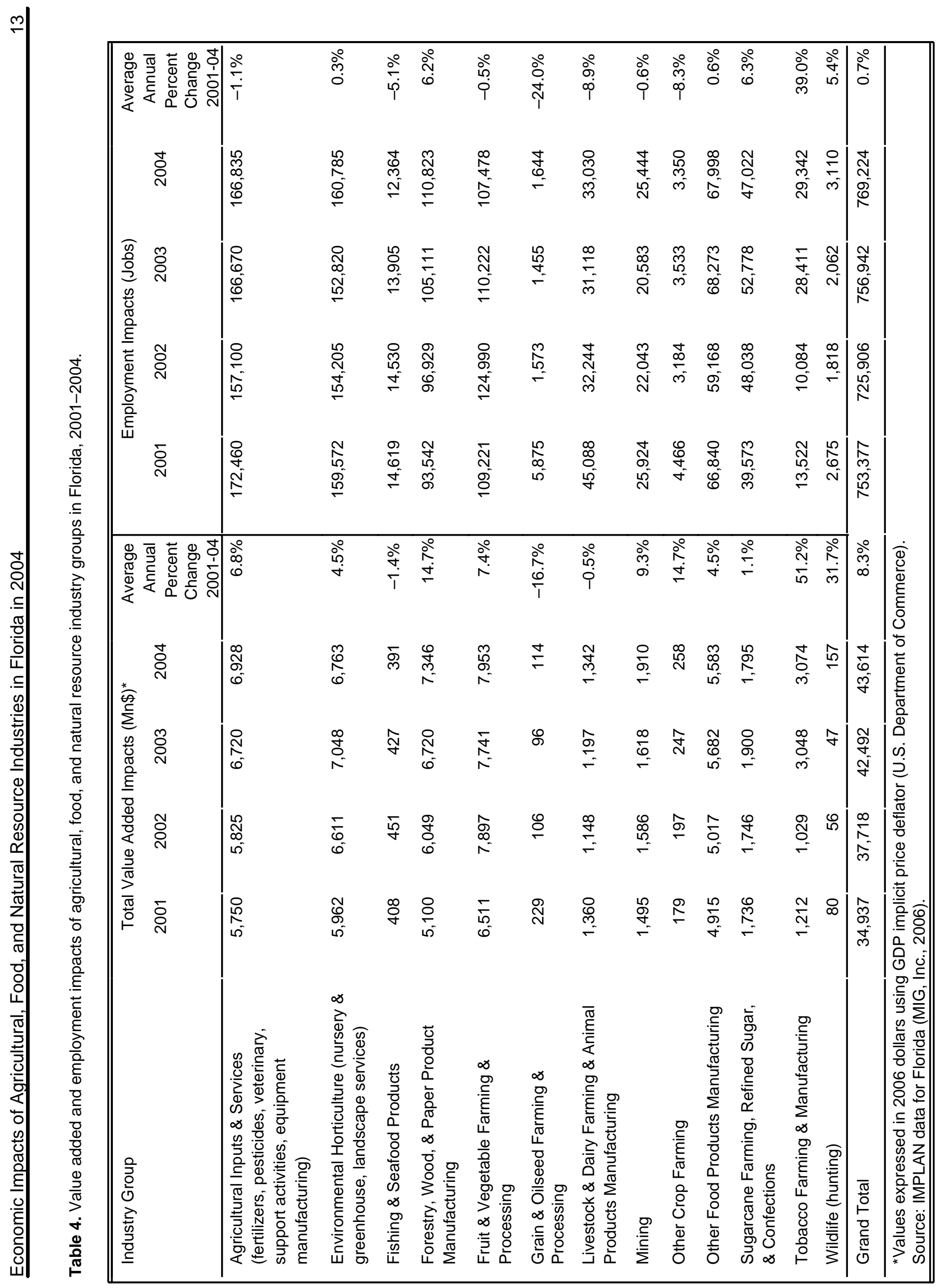


Table 5. Fastest growing sectors of the agricultural, food, and natural resource industries in Florida, 2001-2004.

\begin{tabular}{|c|c|c|}
\hline Industry Sector & $\begin{array}{r}\text { Change in Value } \\
\text { Added Impacts } \\
2001-04^{*} \\
(\mathrm{Mn} \$)\end{array}$ & $\begin{array}{r}\text { Average Annual } \\
\text { Percent Change } \\
2001-04 \\
(\%)\end{array}$ \\
\hline Other tobacco product manufacturing & $1,746.4$ & $49.4 \%$ \\
\hline Vegetable \& melon farming & $1,187.3$ & $33.5 \%$ \\
\hline Landscape services & $1,095.8$ & $11.0 \%$ \\
\hline Phosphatic fertilizer manufacturing & $1,030.9$ & $19.2 \%$ \\
\hline Forest nurseries, forest products, \& timber tracts & 640.5 & $37.4 \%$ \\
\hline Soft drink \& ice manufacturing & 572.8 & $8.7 \%$ \\
\hline Engineered wood member \& truss manufacturing & 482.0 & $29.4 \%$ \\
\hline Paper \& paperboard mills & 397.1 & $11.9 \%$ \\
\hline Sanitary paper product manufacturing & 396.4 & $33.8 \%$ \\
\hline Fruit farming & 338.6 & $5.6 \%$ \\
\hline Wood windows \& door manufacturing & 228.3 & $97.6 \%$ \\
\hline Breweries & 222.8 & $10.1 \%$ \\
\hline Poultry \& egg production & 214.3 & $40.8 \%$ \\
\hline Pesticide \& other agricultural chemical manufacturing & 178.1 & $30.5 \%$ \\
\hline Oil \& gas extraction & 177.8 & $331.0 \%$ \\
\hline Paperboard container manufacturing & 127.0 & $5.8 \%$ \\
\hline Stone mining \& quarrying & 122.8 & $12.2 \%$ \\
\hline Sawmills & 115.4 & $32.3 \%$ \\
\hline Cigarette manufacturing & 107.8 & $562.9 \%$ \\
\hline Veterinary services & 102.3 & $5.1 \%$ \\
\hline Sand, gravel, clay, \& refractory mining & 101.5 & $15.9 \%$ \\
\hline
\end{tabular}


Table 6. Value added and employment of all industry groups in Florida in 2004.

\begin{tabular}{|c|c|c|}
\hline Industry Group & $\begin{array}{r}\text { Employment } \\
\text { (Jobs) }\end{array}$ & $\begin{array}{r}\text { Total Value Added } \\
(\mathrm{Mn} \$)^{*}\end{array}$ \\
\hline Real Estate \& Financial Services & 871,754 & 89,283 \\
\hline Professional \& Technical Services & $1,536,601$ & 79,226 \\
\hline Private Households & 148,282 & 46,586 \\
\hline Health Care & 774,462 & 43,413 \\
\hline Retail Trade & 929,430 & 41,974 \\
\hline Construction & 800,907 & 41,542 \\
\hline Wholesale Trade & 371,397 & 40,188 \\
\hline Government & 411,116 & 39,675 \\
\hline Travel, Food, \& Entertainment Services & $1,011,025$ & 35,387 \\
\hline Education & 816,919 & 35,117 \\
\hline Information \& Communications & 267,527 & 30,343 \\
\hline Manufacturing & 321,123 & 26,662 \\
\hline Consumer Services & 468,846 & 21,800 \\
\hline $\begin{array}{l}\text { Agricultural, Food, Natural Resources, \& } \\
\text { Related Manufacturing \& Services }{ }^{\star \star}\end{array}$ & 390,184 & 19,795 \\
\hline Transportation & 314,768 & 19,308 \\
\hline Utilities & 29,518 & 10,653 \\
\hline Social Services \& Organizations & 246,986 & 5,328 \\
\hline Miscellaneous Residual Accounts & 0 & -410 \\
\hline Grand Total & $9,710,846$ & 625,870 \\
\hline \multicolumn{3}{|c|}{$\begin{array}{l}\text { *Values expressed in } 2006 \text { dollars using GDP implicit price deflator (U.S. Department of } \\
\text { Commerce). } \\
\text { ** Values for some manufacturing and service sectors within agricultural, food, and natural } \\
\text { resources were netted out of other industry groups. } \\
\text { Source: IMPLAN data for Florida (MIG, Inc., 2006). }\end{array}$} \\
\hline
\end{tabular}

